\title{
Biomass and photosynthetic activity of phototrophic picoplankton in coral reef waters (Moorea Island, French Polynesia)*
}

\author{
Louis Legendre ${ }^{1}$, Serge Demers ${ }^{2}$, Bruno Delesalle ${ }^{3,4}$, Carmen Harnois $^{5}$ \\ ${ }^{1}$ Département de biologie, Université Laval, Québec, Québec, Canada G1K 7P4 \\ ${ }^{2}$ Institut Maurice-Lamontagne, Ministère des Pêches et des Océans, 850 route de la Mer, Mont-Joli, Québec, Canada G5H $3 Z 4$ \\ ${ }^{3}$ Centre de l'environnement de Moorea, Museum national d'histoire naturelle et Ecole pratique des hautes études en Polynésie \\ française, BP 1013, Moorea, Polynésie française \\ ${ }^{4}$ Centre de biologie et d'écologie tropicale et méditerranéenne, Ecole pratique des hautes études, Laboratoire de biologie \\ marine et malacologie, Université de Perpignan, F-66025 Perpignan, France \\ ${ }^{5}$ Département d'ophtalmologie, Centre hospitalier de l'Université Laval, 2705 boul. Laurier, Québec, Québec, Canada G1V 4G2
}

\begin{abstract}
In April 1984, chlorophyll $a$ and photosynthetic activity of phytoplankton were measured above a coral reef and in the deep chlorophyll maximum $(100 \mathrm{~m})$ of adjacent oligotrophic oceanic waters. Samples were fractionated into 3 sizes: $0.2-2,2-5$ and $\geq 5 \mu \mathrm{m}$. Total chlorophyll a concentrations were about $0.1 \mathrm{mg} \mathrm{m}^{-3}$, and phytoplankton $>5 \mu \mathrm{m}$ never exceeded $10^{4}$ cells $^{-1}$; picoplankton were not enumerated. Reef samples differed from oceanic waters by containing higher proportions of diatoms and lower proportions of coccolithophorids. Chlorophyll biomass was dominated by the $<2 \mu \mathrm{m}$ fraction in the deep chlorophyll maximum (65 to $90 \%$ ), and by the $\geq 5 \mu \mathrm{m}$ fraction in reef waters (50 to $65 \%)$. In the chlorophyll maximum, cells $<2 \mu \mathrm{m}$ exhibited the lowest $\mathrm{P}_{\mathrm{m}}^{\mathrm{B}}$ of the 3 size fractions. In reef waters, the highest $\mathrm{P}_{\mathrm{m}}^{\mathrm{B}}\left(>20 \mathrm{mg} \mathrm{C} \mathrm{mg} \mathrm{chl}{ }^{-1} \mathrm{~h}^{-1}\right)$ occurred in the $<2 \mu \mathrm{m}$ fraction, above the barrier. Comparisons of estimated daily picoplankton production vs standing stock, above the barrier reef (ca $6 \mathrm{mg} \mathrm{C} \mathrm{m}^{-3} \mathrm{~d}^{-1}$ vs ca $2 \mathrm{mg} \mathrm{C} \mathrm{m} \mathrm{m}^{-3}$ ), suggest active grazing or rapid export of picoplankton. High $P_{\mathrm{m}}^{\mathrm{B}}$ values in reef waters may be explained by high rate of nutrient supply, resulting from land drainage and/or nutrient regeneration. It can be hypothesized that picoplankton cells from the surrounding oligotrophic ocean take advantage of reef nutrients when advected above the barrier; subsequent grazing of small cells by corals and other constituents of the food web ('picoplankton loop'), may contribute to nutrient cycling within the reef ecosystem.
\end{abstract}

\section{INTRODUCTION}

Phytoplankton in oceanic waters are dominated at low latitudes by phycoerythrin-rich cyanobacteria and minute eucaryotic algae, designated as picoplankton (0.2-2.0 $\mu \mathrm{m}_{\text {; }}$ Sieburth et al. 1978) or ultraplankton $(<5-10 \mu \mathrm{m}$; Sverdrup et al. 1942). Picoplankton have recently been the subject of reviews (e.g. Fogg 1986 , Stockner \& Antia 1986) and of a book (Platt \& Li 1986). In oligotrophic oceanic waters they typically account for more than $50 \%$ of the chlorophyll a biomass (e.g.

\footnotetext{
- Contribution to the programs of GIROQ (Groupe interuniversitaire de recherches océanographiques du Québec) and of the Maurice-Lamontagne Institute
}

Herbland \& Le Bouteiller 1981, Platt et al. 1983), with values above $90 \%$ reported by Takahashi \& Hori (1984). Given their high proportions of the photosynthetic biomass, picoplankton account for a large proportion of primary production. They are typically responsible for about 50 to $60 \%$ of total primary production in oceanic oligotrophic waters (Paerl 1977, Herbland \& Le Bouteiller 1981, Li et al. 1983, Platt et al. 1983). Another factor that could enhance their contribution to primary production, at least at depth, is their better photosynthetic efficiency at low irradiance. This has been shown for both laboratory cultures and natural populations (e.g. Glover \& Morris 1981, Morris \& Glover 1981, Platt et al. 1983, Barlow \& Alberte 1985, Glover et al. 1985, 1986a, b). In the chlorophyll max- 
imum, photosynthetic capacity per unit chlorophyll a $\left(\mathrm{P}_{\mathrm{rn}}^{\mathrm{B}}\right)$ has been reported to be higher for picoplankton than for larger cells, for example in North Atlantic oligotrophic waters (Platt et al. 1983). However, picoplankton are also found in high-light environments, and Waterbury et al. (1979) as well as Murphy \& Haugen (1985) have reported larger numbers of cyanobacteria in surface waters. In addition, some of the highest $\mathrm{P}_{\mathrm{m}}^{\mathrm{B}}$ values published for picoplankton are from surface waters (Takahashi \& Bienfang 1983: 14.5 $\mathrm{mg} \mathrm{C} \mathrm{mg} \mathrm{chl}^{-1} \mathrm{~h}^{-1}$; Joint \& Pomroy 1986: $6.5 \mathrm{mg} \mathrm{C}$ $\mathrm{mg} \mathrm{chl}^{-1} \mathrm{~h}^{-1}$ ), which shows that picoplankters can perform well under high-light conditions. This would indicate that picoplankton are capable of sun and shade adaptation, and Prézelin et al. (1986) have suggested that this is primarily accomplished by changing photosynthetic unit number. In addition, high $\mathrm{P}_{\mathrm{m}}^{\mathrm{B}}$ of picoplankters in ammonia-rich waters, both at the surface (Takahashi \& Bienfang 1983: see above) and in the subsurface chlorophyll maximum (Putt \& Prézelin 1985: $5.3 \mathrm{mg} \mathrm{chl}^{-1} \mathrm{~h}^{-1}$ ), can be explained by nutrient uptake faster than that of larger cells (Bienfang \& Takahashi 1983).

Given the importance of photosynthetic picoplankton in oceanic waters that surround coral reefs, it was hypothesized that these organism may play a significant role in reef ecosystems. The area of the Society Islands, in the tropical South Pacific Ocean, is characterized by some of the most oligotrophic and least productive waters of all oceans (Koblentz-Mishke et al. 1970). This area was therefore well suited for assessing the importance of biomass and photosynthetic activity of picoplankton in reef waters, as the extreme oligotrophy of oceanic waters is confronted there to the high productivity of coral reefs.

\section{MATERIAL AND METHODS}

Sampling was conducted around Moorea Island, French Polynesia. On 23 April 1984, samples were collected with Niskin bottles in the deep chlorophyll maximum at the mouth of Opunohu Bay (Stn $\mathrm{M}_{i}$. Fig. 1) at $95,100,105$ and $110 \mathrm{~m}$. These depths corresponded to about $1 \%$ of irradiance at sea surface, given a coefficient of light attenuation $k=0.046 \mathrm{~m}^{-1}$ computed from Secchi depth $D=37 \mathrm{~m}\left(k=1.7 / D_{i}\right.$ Poole \& Atkins 1929). On 24 April, surface water was collected above the barrier reef $(B)$, in mid-lagoon ( $L$ ) and above the fringing reef $(\mathrm{F})$ (Tiahura transect: Fig. 1), and at $100 \mathrm{~m}$ depth on the outer slope of the reef (S).

For each sample, 7 bottles $(280 \mathrm{ml})$ were inoculated with 5.8 (23 April) and 7.0 (24 April) $\mu \mathrm{Ci} \mathrm{H}^{14} \mathrm{CO}_{3}$, and incubated in the laboratory for $4 \mathrm{~h}$ under 7 photon fluence rates ranging from 60 to $1400 \mu \mathrm{Ein} \mathrm{m}^{-2} \mathrm{~s}^{-1}$.
Photosynthetically available radiation (PAR: 400 to $700 \mathrm{~nm})$ was measured using a $4 \pi$ Biospherical irradiance meter. Activity of the $\mathrm{H}^{14} \mathrm{CO}_{3}$ solution was measured on triplicate $50 \mu \mathrm{l}$ samples. The incubating system was based on the linear incubator of Platt \& Jassby (1976). The light source was a $2000 \mathrm{~W}$ tungstenhalogen lamp and the incubator was cooled with running water. At the end of the incubations, samples were serially filtered on Nitex 42 and $20 \mu \mathrm{m}$ and on Nuclepore $10,5,3,2$ and $0.2 \mu \mathrm{m}$. Filters were put into scintillation vials with $0.2 \mathrm{ml} 0.5 \mathrm{~N} \mathrm{HCl}$ (Lean \& Burnison 1979), and $10 \mathrm{ml}$ Aquasol was added before counting the samples on a Kontron liquid scintillation counter (Pugh 1973). Activities were converted into carbon assimilation using the same value for total $\mathrm{CO}_{2}$ $\left(25 \mathrm{~g} \mathrm{~m}^{-3}\right)$ as in Sournia \& Ricard (1976). Simultaneously, $280 \mathrm{ml}$ samples were size-fractionated on Nuclepore filters for chlorophyll a determinations, and filtrates frozen for nutrient analyses on a Technicon autoanalyzer (Strickland \& Parsons 1972). A few days after the experiments, frozen filters were extracted for $24 \mathrm{~h}$ in $90 \%$ acetone at $0{ }^{\circ} \mathrm{C}$, and chlorophyll a as well as pheopigments measured following the fluorometric method of Yentsch \& Menzel (1963). Data were pooled into 3 size fractions for analysis: $<2 \mu \mathrm{m}, 2-5 \mu \mathrm{m}$, and $\geq 5 \mu \mathrm{m}$. Subsamples were preserved in $4 \%$ neutral formalin, for phytoplankton enumeration of cells $>5 \mu \mathrm{m}$ using the Utermöhl method (Lund et al. 1958). As no epifluorescence microscope was available on site, enumeration of cells $<5 \mu \mathrm{m}$ (Hobbie et al. 1977 . Glover et al. 1985) was not possible. These measurements were not made on surface samples from $S t n$, given the very low concentrations of chlorophyll $a$ at the time of sampling (ca $0.03 \mathrm{mg} \mathrm{m}^{-3}$ ).

In addition, samples were collected on various occasions, between 5 April and 2 May 1984, at the same sites as above and also at an open water station $5 \mathrm{~km}$ north of Tahiti Island (Stn C, $1000 \mathrm{~m}$ depth; Fig. 1). Pigments were measured as above, on samples filtered in duplicate on both Millipore $0.45 \mu \mathrm{m}$ and Whatman GF/C. As the mean difference between duplicate samples for each filter type was less than $5 \%$, the 2 values were averaged. Phytoplankton were enumerated on several of these samples

\section{RESULTS}

Table 1 gives background data collected at various stations and depths, between 5 April and 2 May 1984. Table 2 gives similar information for samples collected on 23 and 24 April. Total concentrations of chlorophyll a were about $0.1 \mathrm{mg} \mathrm{m}^{-3}$. Numbers of cells and taxonomic composition at all the water column samples were quite similar. These differed from reef samples by 
Fig. 1. Sampling sites. CORIOLIS station (C); mouth of Opunohu Bay (M); and Tiahura transect: fringing reef $(F)$, mid-lagoon (L), barrier reef (B) and outer slope of the reef (S)

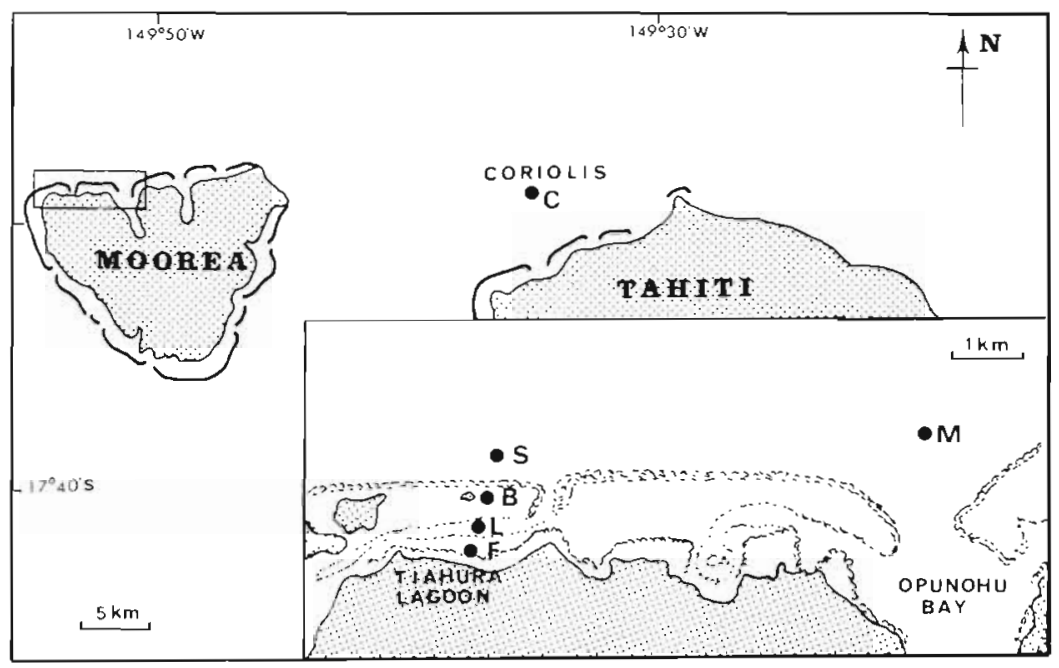

Table 1. Average chlorophyll a and pheopigments, number of cells and relative abundance of phytoplankton taxa in samples collected between 5 April and 2 May 1984 (excluding samples in Table 2). Picoplankton were not enumerated

\begin{tabular}{|c|c|c|c|c|c|}
\hline & \multicolumn{2}{|c|}{ Open ocean (C) } & \multicolumn{2}{|c|}{ Moorea Island (M) } & \multirow{2}{*}{$\begin{array}{l}\text { Fringing } \\
\text { reef }(F)\end{array}$} \\
\hline & $50 \mathrm{~m}$ & $100 \mathrm{~m}$ & $50 \mathrm{~m}$ & $100 \mathrm{~m}$ & \\
\hline No. samples & 4 & 4 & $4^{\mathrm{d}}$ & $10^{\mathrm{b}}$ & 1 \\
\hline Chlorophyll a ( $\left.\mathrm{mg} \mathrm{m}^{-3}\right)$ & 0.100 & 0.025 & 0.098 & 0.173 & 0.131 \\
\hline Pheopigments (mg m${ }^{-3}$ ) & 0.050 & 0.042 & 0.041 & 0.118 & 0.182 \\
\hline Cells $1^{-1}(>5 \mu \mathrm{m})$ & 1740 & 970 & 4810 & 4120 & 10410 \\
\hline$\%$ Dinoflagellates & 69 & 70 & 54 & 32 & 18 \\
\hline$\%$ Coccolithophorids & 24 & 12 & 28 & 36 & 0 \\
\hline$\%$ Diatoms & 4 & 9 & 11 & 12 & 48 \\
\hline$\%$ Cyanophytes & 0 & 2 & 0 & 6 & 21 \\
\hline$\%$ Others & 3 & 7 & 7 & 14 & 12 \\
\hline \multicolumn{6}{|l|}{${ }^{a}$ Cell enumeration: 1 sample } \\
\hline
\end{tabular}

Table 2. Chlorophyll $a$ and pheopigments, number of cells and relative abundance of phytoplankton taxa in Figs. 2 and 3 (collected on 23 and 24 April 1984). Averages of 4 depths (95 to $110 \mathrm{~m}$ ) are given for samples from the mouth of Opunohu Bay. picoplankton were not enumerated

\begin{tabular}{|c|c|c|c|c|c|}
\hline & $\begin{array}{c}95 \mathrm{~m} \text { to } \\
110 \mathrm{~m}(\mathrm{M})\end{array}$ & $\begin{array}{c}\text { Slope (S) } \\
100 \mathrm{~m}\end{array}$ & Barrier (B) & $\begin{array}{l}\text { Coral reef } \\
\text { Lagoon (L) }\end{array}$ & Fringing $(F)$ \\
\hline Chlorophyll a ( $\left.\mathrm{mg} \mathrm{m}^{-3}\right)$ & 0.103 & 0.196 & 0.096 & 0.120 & 0.082 \\
\hline Pheopigments ( $\mathrm{mg} \mathrm{m}^{-3}$ ) & 0.076 & 0.072 & 0.161 & 0.111 & 0.151 \\
\hline Cells $l^{-1}(>5 \mu \mathrm{m})$ & 1720 & 9310 & 7370 & 4860 & 6680 \\
\hline$\%$ Dirioflagellates & 33 & 52 & 47 & 60 & 41 \\
\hline$\%$ Coccolithophorids & 52 & 32 & 4 & 3 & 0 \\
\hline$\%$ Diatoms & 5 & 11 & 29 & 22 & 44 \\
\hline$\%$ Cyanophytes & 0 & 0 & 9 & 6 & 7 \\
\hline$\%$ Others & 10 & 5 & 10 & 8 & 6 \\
\hline
\end{tabular}

their relatively high proportions of coccolithophorids $(>20 \%$ versus almost zero in reef waters), and low proportions of diatoms $(<10 \%$ versus up to $50 \%$ in reef waters).

Fig. 2 shows the distribution of chlorophyll a among the 3 size fractions. Concentrations and percentages were very similar for the 5 deep samples collected near Moorea Island (upper panel), where the smallest size fraction $(<2 \mu \mathrm{m})$ dominated the biomass. This was very different from reef samples (bottom panel), where large particles $(\geq 5 \mu \mathrm{m})$ accounted for more than $50 \%$ of the biomass. 


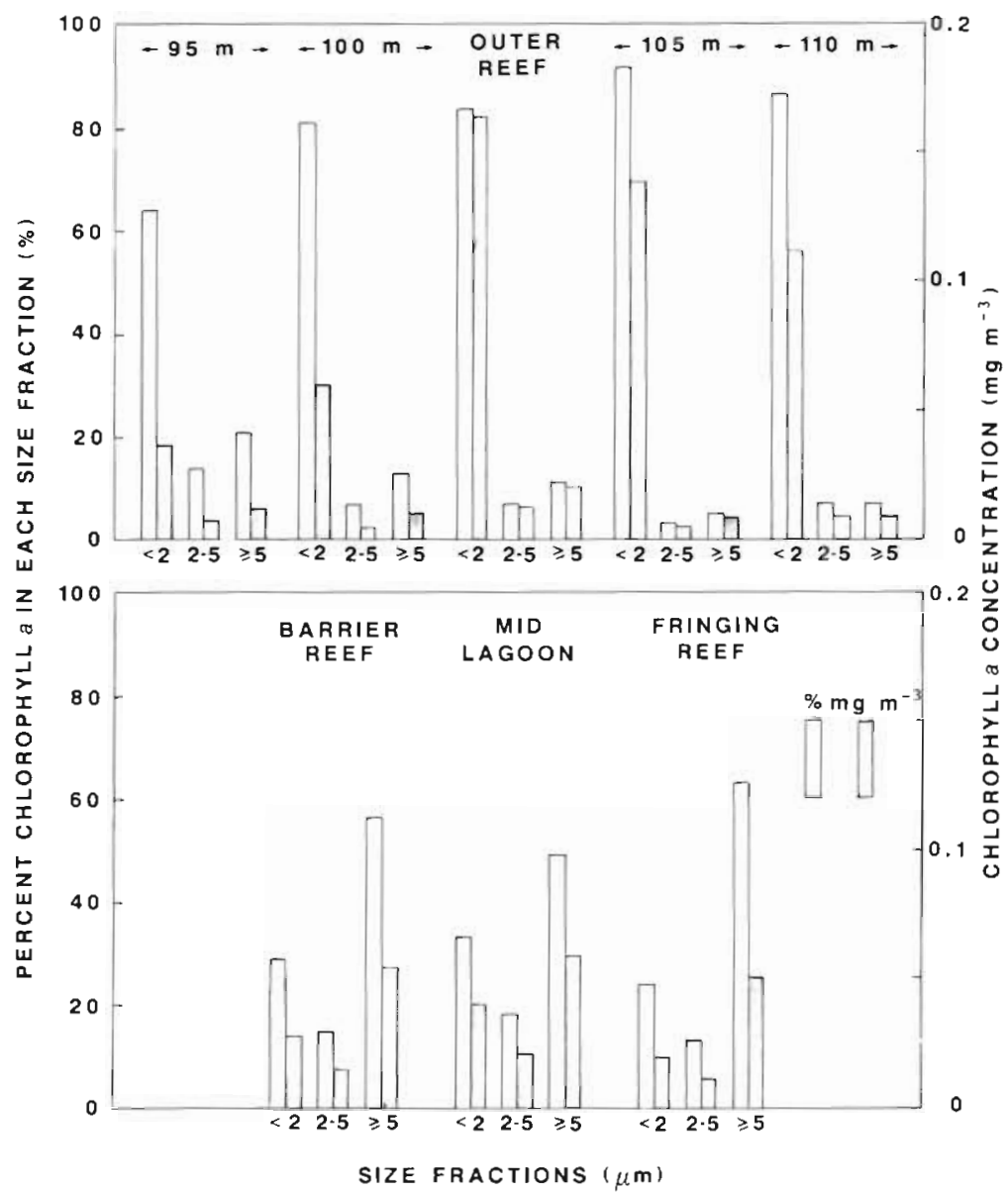

Fig. 2. Relative abundance and concentration of chlorophyll a among the 3 size fractions. Top panel: sample collected at $100 \mathrm{~m}$ on the outer slope of the reef (Stn S) and samples collected at the mouth of Opunohu Bay (95 to $110 \mathrm{~m}$; Stn M). Botton panel: samples from the 3 reef stations (Stns B, L and F)
The lowest irradiance in the incubator was $60 \mu$ Ein $\mathrm{m}^{-2} \mathrm{~s}^{-1}$. Detailed photosynthesis versus irradiance measurements (down to $<1 \mu$ Ein $\mathrm{m}^{-2} \mathrm{~s}^{-1}$ ), made a few days later on samples from the fringing reef (Stn F) and $100 \mathrm{~m}$ depth (Stn M), showed saturation to occur at $\approx 60 \mu$ Ein $\mathrm{m}^{-2} \mathrm{~s}^{-1}$. Photosynthetic measurements made under the highest irradiances were thus above saturation, and they were used as replicates in computing estimates of maximum potential production per unit chlorophyll a ( $\mathrm{P}_{\mathrm{m}}^{\mathrm{B}}$; Fig. 3). Confidence intervals were generally narrow, indicating similar photosynthesis under all the incubation irradiances. Cells $<2 \mu \mathrm{m}$ at depth near Moorea Island exhibited the lowest $\mathrm{P}_{\mathrm{m}}^{\mathrm{B}}$ of the 3 size fractions (top panel); in reef waters (bottom panel), the highest $\mathrm{P}_{\mathrm{r}}^{\mathrm{B}}$ was in the $<2 \mu \mathrm{m}$ fraction, above the barrier.

Table 3 gives average concentrations of dissolved inorganic nutrients. Concentrations of phosphate and silicate were above detection level at all stations, with somewhat lower $\mathrm{Si}(\mathrm{OH})_{4}$ values near Moorea Island and in reef waters. As expected in an oligotrophic environment, concentrations of $\mathrm{NO}_{3}$ and $\mathrm{No}_{2}$ were very low at the surface, often below detection. Nutrient concentrations on the Tiahura transect are similar to those observed in Moorea waters by Sournia \& Ricard
(1976), and by B. Delesalle (unpubl.) between November 1982 and April 1984; they also correspond to values reported for other coral reefs (D'Elia \& Wiebe in press).

\section{DISCUSSION}

Potential errors resulting from size fractionation have been reviewed by $\mathrm{Li}$ (1986). He concluded that there is no general rule for cell retention on filters, since this depends not only on pore size and vacuum pressure but also on differences in taxa and physiology. In some cases, biomass of small size fractions may be underestimated. On the other hand, fragments of eukaryotic cells may be caught on small-pore filters during ${ }^{14} \mathrm{C}$ experiments, and incorrectly attributed to carbon fixed by picoplankton (Waterbury et al. 1986). However, this is unlikely for the present study given that the $<2 \mu \mathrm{m}$ fraction most often had the lowest $\mathrm{P}_{\mathrm{m}}^{8}$ of the 3 size fractions (Fig. 3).

\section{Biomass, taxonomic composition and photosynthesis}

Chlorophyll and pheopigment concentrations measured on Millipore $0.45 \mu \mathrm{m}$ filters were respectively 




Fig. 3. Maximum potential photosynthesis in each size fraction normalized to unit chlorophyll a $\left(\mathrm{P}_{\mathrm{m}}^{\mathrm{B}}\right)$. Mean values and confidence intervals $(\alpha=0.05)$ for the $\leq 6$ highest incubation irradiances. Top panel: sample collected at $100 \mathrm{~m}$ on the outer slope of the reef (Stn S) and samples collected at the mouth of Opunohu Bay (95 to $110 \mathrm{~m}_{\text {; }}$ Stn M). Bottom panel: samples from the 3 reef stations (Stns B, L and F)

Table 3. Average concentrations $\left(\mathrm{mmol} \mathrm{m}^{-3}\right)$ of dissolved inorganic nutrients during April 1984. Sampling sites in Fig 1

\begin{tabular}{|lrlcc|}
\hline & $\mathrm{NO}_{3}$ & $\mathrm{NO}_{2}$ & $\mathrm{PO}_{4}$ & $\mathrm{Si}(\mathrm{OH})_{4}$ \\
\hline Open ocean (C) & & & & \\
$50 \mathrm{~m}$ & 1.74 & 0.08 & 0.65 & 5.31 \\
$100 \mathrm{~m}$ & 2.48 & 0.11 & 0.82 & 6.74 \\
Moorea Island & & & & \\
$0 \mathrm{~m} \mathrm{(S)}$ & $<0.02$ & 0.07 & 0.49 & 1.72 \\
$50 \mathrm{~m} \mathrm{(M)}$ & 0.74 & 0.10 & 0.52 & 2.43 \\
$100 \mathrm{~m}(\mathrm{M})$ & 0.47 & 0.09 & 0.49 & 2.00 \\
Barrier reef (B) & $<0.02$ & 0.07 & 0.46 & 1.78 \\
Mid-lagoon (L) & 0.03 & 0.09 & 0.50 & 1.90 \\
Fringing reef (F) & 0.13 & 0.12 & 0.50 & 2.07 \\
& & & & \\
\hline
\end{tabular}

$40 \%$ and $25 \%$ higher than those on Whatman GF/C filters (paired tests, $N=22: t=5.9$ and $t=4.4$, $p<0.001$ ). This shows that a significant fraction of the picoplankton passed through GF/C filters, as already noted by Herbland \& Le Bouteiller (1981) and Phinney $\&$ Yentsch (1985). Accordingly, values in Table 1 are those from the Millipore $0.45 \mu \mathrm{m}$ filters.
Chlorophyll a concentrations were generally low (Tables 1 and 2), and of the same order of magnitude as those reported for the same reef waters by Sournia \& Ricard (1976) and Sournia et al. (1981). They are also similar to values measured by Ricard \& Delesalle (1982) in the upper $100 \mathrm{~m}$ of the water column, along a $3 \mathrm{~km}$ transect on the leeward side of Moorea Island. Typical concentrations at $50 \mathrm{~m}$ were ca $0.1 \mathrm{mg} \mathrm{m}^{-3}$, both in the open ocean (Stn C) and near Moorea Island (Stn M). Concentrations were almost twice as high at $100 \mathrm{~m}$ near the island (Stns $M$ and $S$ ); these were associated with a deep chlorophyll maximum observed by $B$. Delesalle (unpubl.) at $100 \mathrm{~m}$ depth north of Moorea Island, from the reef up to $20 \mathrm{~km}$ offshore. Picoplankton dominated the chlorophyll maximum (Fig. 2), with proportions (65 to $90 \%$ ) equivalent to those reported in similar environments (see 'Introduction'). In reef waters, chlorophyll was $>0.1 \mathrm{mg} \mathrm{m}^{-3}$, and the smallsized fraction accounted for lower proportions of the biomass than in the chlorophyll maximum.

Cell concentrations were in general quite low, and reef communities were dominated by diatoms, followed by dinoflagellates (Tables 1 and 2). Both in terms of cell numbers and taxonomic composition, waters at $100 \mathrm{~m}$ near Moorea Island (Stns $M$ and $S$ ) were somewhat intermediate between reef and truly oceanic (Stn C) waters. Lower Si:P ratios (data in Table 3) in Moorea and reef waters $(4: 1)$ relative to the open ocean $(8: 1)$ probably reflect the importance of diatoms (both planktonic and benthic) in the reef ecosystem.

In the absence of replicate samples for reef waters, it could be argued that actual differences between sites were perhaps not significantly larger than the variability within sites. It must be noted that photosynthetic measurements were replicated for each sample and size fraction, which allowed the computation of means and confidence intervals (Fig. 3). In general, there were no significant differences among samples from the chlorophyll maximum concerning the distribution of photosynthesis among the size fractions (Fig. 3, top panel). In contrast, samples from reef waters were significantly different from each other (Fig. 3, bottom panel). Above the barrier, $\mathrm{P}_{\mathrm{m}}^{\mathrm{B}}$ in the $<2 \mu \mathrm{m}$ fraction was the highest of all the samples. The same was true above the fringing reef, for the 2-5 $\mu \mathrm{m}$ fraction.

In the chlorophyll maximum (Fig. 3, top panel), $\mathrm{p}_{\mathrm{m}}^{\mathrm{B}}$ in the $<2 \mu \mathrm{m}$ fraction was lower than in the other size fractions. This agrees with Joint \& Pomroy (1986) who found little evidence that picoplankton were more adapted to low light conditions than the larger phytoplankton cells, and also with Probyn (1985) who reported that the small-sized fraction turned over at a slower rate than the whole community. Such results differ from studies (see 'Introduction') where higher $\mathrm{P}_{\mathrm{m}}^{\mathrm{B}}$ have been reported for picoplankton, which may have 
been caused by differences in nutrient environment or taxonomic composition.

Above the barrier reef (Fig. 3 bottom panel), the highest photosynthetic activity $\left(\mathrm{P}_{\mathrm{m}}^{\mathrm{B}}\right)$ took place in the $<2 \mu \mathrm{m}$ fraction. This shows that picoplankton can sometimes be photosynthetically very active in highlight environments. Above the barrier reef and in midlagoon, low $\mathrm{P}_{\mathrm{m}}^{\mathrm{B}}$ in the $\geq 5 \mu \mathrm{m}$ fraction were associated with relatively high chlorophyll concentrations (Fig. 2, bottom panel). These may reflect the presence of 'pseudoplankton' (Odum \& Odum 1955, Gerber \& Marshall 1974), which are made of organic debris (photosynthetically inactive chlorophylly that could account for the relatively low $\mathrm{P}_{\mathrm{m}}^{\mathrm{B}}(\geq 5 \mu \mathrm{m})$ on the barrier reef and in mid-lagoon. The importance of pseudoplankton in reef waters has been reviewed by Sournia (1977), and similar lowering of $\mathrm{P}_{\mathrm{m}}^{\mathrm{B}}$ has been reported for the littoral zone in the St Lawrence Estuary as caused by resuspension of photosynthetically inactive benthic diatoms through wind action (Demers et al. 1987).

\section{Picoplankton in reef ecosystems}

High photosynthetic rates in reef waters $\left(\mathrm{P}_{\mathrm{m}}^{\mathrm{B}}\right.$ : Fig. 3), sometimes close to the theoretical maximum of $25 \mathrm{mg} \mathrm{C}$ mg $\mathrm{chl}^{-1} \mathrm{~h}^{-1}$ (Falkowski 1981), may be explained by increased rates of nutrient supply. Nutrient concentrations in Table 3 are not really useful in that respect, since phytoplankton production is not regulated by ambient nutrient levels but rather by rates of supply (Menzel \& Ryther 1961). This explains why oligotrophic waters can sometimes support high production rates (Laws et al. 1984). Nutrient supply in Moorea waters could have been enhanced by land drainage and regeneration by benthic and pelagic grazers, which are mechanisms of nutrient enrichment postulated for the 'island mass effect' (Sander 1981). Linley \& Koop (1986) have reported rapid response of pelagic bacteria (including heterotrophic cells) to organic matter and nutrient enrichment, when starved oceanic cells with very high affinities for dissolved substrates meet reef waters. Concerning phototrophic picoplankton in surface waters, Bienfang \& Takahashi (1983) observed rapid increases (hours) of $\mathrm{P}^{\mathrm{B}}$ in response to nutrient enrichment, which they explained by high rates of nutrient uptake, e.g. $\mathrm{NH}_{4}$ assimilation $75 \%$ faster for the $<3 \mu \mathrm{m}$ fraction than for the $3-20 \mu \mathrm{m}$ cells. Such nutrient effects could explain the high photosynthetic rates observed in reef waters. Similarly, nutrient enrichment at the mouth of Opunohu Bay could explain $\mathrm{P}_{\mathrm{m}}^{\mathrm{B}}$ values (Fig. 3) somewhat higher than those reported elsewhere for deep picoplankton (in general $\leq 2 \mathrm{mg} \mathrm{C} \mathrm{mg} \mathrm{chl}{ }^{-1} \mathrm{~h}^{-1}$; references in 'Introduction').

Estimations of carbon:chlorophyll ratio for the cyanobacterium Synechococcus sp. range between 40 for a surface water population (Joint \& Pomroy 1986) and 130 for a laboratory culture (Cuhel \& Waterbury 1984). Using a conservative estimate of 60 , chlorophyll a concentrations (B) for the $<2 \mu \mathrm{m}$ fraction (Fig. 2) can be converted into carbon, which gives standing stocks of ca $2 \mathrm{mg} \mathrm{C} \mathrm{m}{ }^{-3}$ for the reef transect. The ratio of maximum hourly production to daily production is about 10 for pelagic bacteria in coral reef waters (Moriarty et al. 1985). Given this ratio and the fact that the highest irradiances in the incubator corresponded to $\mathrm{Ca} 1200$ $\mu$ Ein $\mathrm{m}^{-2} \mathrm{~s}^{-1}$ measured at sea surface around noontime, daily production of picoplankton can be estimated as $\left[10 \mathrm{~B} \mathrm{P}^{\mathrm{B}}\right] \approx 2 \mathrm{mg} \mathrm{C} \mathrm{m}{ }^{-3} \mathrm{~d}^{-1}$ in mid-lagoon and above the fringing reef, and $\approx 6 \mathrm{mg} \mathrm{C} \mathrm{m} \mathrm{m}^{-3} \mathrm{~d}^{-1}$ above the barrier reef. For the barrier reef, comparison of production estimates to standing stocks suggests active grazing or rapid export of picoplankton. Similar data for the Great Barrier Reef led Moriarty et al. (1985) to conclude that bacteria were actively grazed in reef waters.

At high tide in Moorea, oceanic waters are advected above the barrier into the lagoon by the breaking of waves on the reef, while at low tide, water flows out of the lagoon through passes (Ricard 1980). As a consequence, picoplankton would be advected above the barrier reef, from the ocean into the lagoon. This circulation pattern, combined with the increased nutrient uptake suggested above, would be consistent with the high photosynthetic rates measured for picoplankton, especially above the barrier reef. It can be hypothesized that picoplankton cells from the surrounding oligotrophic ocean take advantage of reef nutrients when advected above the barrier reef. High daily production relative to standing stock could indicate active grazing of picoplankton on the barrier reef, by corals and other benthic suspension-feeders and also zooplankton (Moriarty et al. 1985, Linley \& Koop 1986). Such a 'picoplankton loop' may contribute to nutrient cycling within the reef ecosystem.

Acknowledgements. This research was funded by the Centre de l'environnement de Moorea, the Natural Sciences and Engineering Research Council of Canada (L. L.), and the Maurice-Lamontagne Institute, Department of Fisheries and Oceans (S.D.). The authors wish to thank Dr Lafon for use of a liquid scintillation counter at Hôpital Jean-Prince of Tahiti; the director of the LESE, Commissariat à l'énergie atomique, Papeete, for use of laboratory facilities; the captain and the crew of the oceanographic vessel 'Coriolis' for sampling at sea; Dr M.R. Lewis, Dalhousie University, for Nucleopore filters; and Mr G. Dunoyer de Segonzac, scientific advisor at the French Embassy in Ottawa, for assistance with administrative matters. We also benefited from scientific exchanges in Moorea with Drs M. Ricard, then directeur adjoint of the Centre de l'environnement, and J.P. Renon, Université d'Orléans. Drs R. P.M. Bak, C.F. D'Elia, R. C. Dugdale and A Sournia as well as 3 reviewers provided useful suggestions and criticisms on earlier versions of the manuscript. Ms M. J Martineau helped with data analysis. 


\section{LITERATURE CITED}

Barlow, R. G., Alberte, R. S. (1985). Photosynthetic characteristics of phycoerythrin-containing marine Synechococcus spp. I. Response to growth photon flux density. Mar. Biol. 86: 63-74

Bienfang, P. K., Takahashi, M. (1983). Ultraplankton growth rates in a subtropical ecosystem. Mar. Biol. 76: 213-218

Cuhel, R. L., Waterbury, J. B. (1984). Biochemical composition and short term nutrient incorporation patterns in a unicellular marine cyanobacterium, Synechococcus (WH7803). Limnol. Oceanogi 29: 370-374

D'Elia, C. F., Wiebe, W. J. (in press). Biogeochemical nutrient cycles in coral reef ecosystems. In: Dubinsky, Z. (ed.) Coral reef ecosystems. Ecosystems of the world series. Elsevier, Amsterdam

Demers, S., Therriault, J.C., Bourget, E., Bah, A. (1987). Resuspension in the shallow sublittoral zone of a microtidal estuarine environment: wind influence. Limnol. Oceanogr. 32: 327-339.

Falkowski, P. G. (1981). Light-shade adaptation and assimilation numbers. J. Plankton Res. 3: 203-216

Fogg, G. E. (1986). Picoplankton. Proc. R. Soc. Lond. B. 228: $1-30$

Gerber, R., Marshall, N. (1974). Reef pseudoplankton in lagoon trophic systems. In: Cameron, A.M. et al. (eds.) Proceedings of the second international symposium on coral reefs, Vol. I. Great Barrier Reef Committee, Brisbane, p. 105-107

Glover, H. E., Morris, I. (1981). Photosynthetic characteristics of coccoid marine cyanobacteria. Arch. Mikrobiol. 129: $42-46$

Glover, H. E., Phinney, D. A., Yentsch, C.S. (1985). Photosynthetic characteristics of picoplankton compared with those of larger phytoplankton populations, in various water masses in the Gulf of Maine. Biol. Oceanogr 3: 223-248

Glover, H. E., Campbell, L., Prézelin, B. B. (1986a). Contribution of Synechococcus spp. to size-fractionated primary productivity in three water masses in the Northwest Atlantic Ocean. Mar. Biol. 91: 193-203.

Glover, H. E, Keller, M.D., Guillard, R. R. L. (1986b). Light quality and oceanic ultraphytoplankters. Nature, Lond. 319: 142-143

Herbland, A., Le Bouteiller, A. (1981). The size distribution of phytoplankton and particulate organic matter in the Equatorial Atlantic Ocean: importance of ultraseston and consequences. J. Plankton Res. 3: 659-673

Hobbie, J. E., Daley, R. J., Jasper, S. (1977). Use of Nuclepore filters for counting bacteria by fluorescence mnicroscopy. Appl. environ. Microbiol. 33: 1225-1228

Joint, I. R., Pomroy, A. J. (1986). Photosynthetic characteristics of nanoplankton and picoplankton from the surface mixed layer Mar. Biol. 92: 465-474

Koblentz-Mishke, O. I., Volkovinsky, V. V., Kabanova, Yu. G. (1970). Plankton primary production of the world ocean. In: Wooster, W (ed.) Scientific exploration of the South Pacific. Nat. Acad. Sci, Washington, p. 183-193

Laws, E. A., Redalje, D. G., Haas, L.W., Bienfang, P. K., Eppley, R.W., Harrison, W. G., Karl, D.M., Marra, J. (1984). High phytoplankton growth and production rates in oligotrophic Hawaiian coastal waters. Limnol. Oceanogr 29: 1161-1169

Lean, D. R. S., Burnison, B.K. (1979). An evaluation of errors in the ${ }^{14} \mathrm{C}$ method of primary production measurement. Limnol. Oceanogr 24: 917-928

Li, K.W. K. (1986). Experimental approaches to field measure- ments: methods and interpretation. In: Platt, T., Li, K. W. K. (eds.) Photosynthetic picoplankton. Can. Bull. Fish. Aquat. Sci. 214: 251-286

Li, W. K.W., Subba Rao D. V., Harrison, W. G., Smith, J.C., Cullen, J. J., Irwin, B., Platt, T (1983). Autotrophic picoplankton in the tropical ocean. Science 219: 292-295

Linley, E. A. S., Kopp, K. (1986). Significance of pelagic bacteria as a trophic resource in a coral reef lagoon, One Tree Island, Great Barrier Reef. Mar. Biol. 92: 457-464

Lund, J.W. G., Kipling, C., Lecren, E.D. (1958). The inverted microscope method of estimating algal numbers and the statistical basis of estimations by counting. Hydrobiologia 11: $143-170$

Menzel, D.W., Ryther, J.H. (1961). Nutrients limiting the production of phytoplankton in the Sargasso Sea, with special reference to iron. Deep Sea Res. 7: 276-281

Moriarty, D. W. J., Pollard, P. C., Hunt, W. G. (1985). Temporal and spatial variation in bacterial production in the water column over a coral reef. Mar. Biol. 85: 285-292

Morris, I., Glover, H.E. (1981). Physiology of photosynthesis by marine coccoid cyanobacteria - some ecological implications. Limnol. Oceanogr 26: 957-961

Murphy, L.S., Haugen, E.M. (1985). The distribution and abundance of phototrophic ultraplankton in the North Atlantic. Limnol. Oceanogr. 30: 47-58

Odum, H. T., Odum, E.P. (1955). Trophic structure and productivity of a windward coral reef community on Eniwetok atoll. Ecol. Monogr. 25: 291-320.

Paerl, H.W. (1977). Nanoplankton vs netplankton photosynthetic and heterotrophic activities in Fijian waters of the South Pacific Ocean. Lau-Tonga Bull. 117: 211-221

Phinney, D. A., Yentsch, C.S. (1985). A novel phytoplankton chlorophyll technique: toward automated analysis. J. Plankton Res. 7: 633-642

Platt, T., Jassby. A. D. (1976). The relationship between photosynthesis and light in natural assemblages of marine phytoplankton. J. Phycol. 12: 421-430

Platt, T., Li, K.W. K. (eds.) (1986). Photosynthetic picoplankton. Can. Bull. Fish. Aquat. Sci. 214: 1-583

Platt, T., Subba Rao, D. V., Irwin, B. (1983). Photosynthesis of picoplankton in the oligotrophic ocean. Nature, Lond. 301: $702-704$

Poole, H. H., Atkins, W. R. G. (1929). Photo-electric measurements of submarine illumination throughout the year $J$. mar. biol. Ass. U. K. 16: 297-324

Prézelin, B. B., Putt, M., Glover, H. E. (1986). Diurnal patterns in photosynthetic capacity and depth-dependent photosynthesis-irradiance relationships in Synechococcus spp. and larger phytoplankton in three water masses in the Northwest Atlantic Ocean. Mar. Biol. 91: 205-217

Probyn, T.A. (1985). Nitrogen uptake by size-fractionated phytoplankton populations in the southern Benguela upwelling system. Mar. Ecol. Prog. Ser. 22: 249-258

Pugh, P. R. (1973). An evaluation of liquid scintillation counting techniques for use in aquatic primary production studies. Limnol. Oceanogr. 18: 310-319

Putt, M., Prézelin, B. B. (1985). Observations of diel patterns of photosynthesis in cyanobacteria and nannoplankton in the Santa Barbara Channel during el Nino. J. Plankton Res. 7 : $779-790$

Ricard, M. (1980). Diminution de la production primaire du lagon de Tiahura (île de Moorea, Polynésie française) sous l'influence de la pollution liée à l'exploitation de sables coralliens. Cah. Indo-Pacifique 2(1): 73-90

Ricard, M., Delesalle, B. (1982). Approche d'un effet de masse insulaire en Polynésie française: phytoplancton des eaux côtières de Tahiti. Oceanis 8: 309-318 
Sander, F. (1981). A preliminary assessment of the main causative mechanisms of the 'island mass' effect of Barbados. Mar. Biol. 64: 199-205

Sieburth, J. McN., Smetacek, V., Lenz, J. (1978). Pelagic ecosystem structure: heterotrophic compartments of the plankton and their relationship to plankton size fractions. Limnol. Oceanogr. 23: 1256-1263

Sournia, A. (1977). Analyse et bilan de la production primaire dans les récifs coralliens. Annls. Inst. océanogr. Paris 53: $47-74$

Sournia, A., Delesalle, B., Ricard, M. (1981). Premiers bilans de production organique et de calcification d'un récifbarrière de la Polynésie Française. Oceanologica Acta 4: $423-431$

Sournia, A., Ricard, M. (1976). Phytoplankton and its contribution to primary productivity in two coral reef areas of French Polynesia. J. exp. mar. Biol. Ecol. 21: 129-140

Stockner, J.G., Antia, N.J. (1986). Algal picoplankton from marine and freshwater ecosystems: a multidisciplinary perspective. Can. J. Fish. Aquat. Sci. 43: 2472-2503

Strickland, J. D. H., Parsons, T. R. (1972). A practical handbook of seawater analysis, 2nd edn. Can. Bull. Fish. Aquat. Sci. $167: 1-310$

Sverdrup, H. U., Johnson, M.W., Fleming, R. H. (1942). The oceans. Prentice-Hall, Englewood Cliffs, N. J.

Takahashi, M., Bienfang, P. K. (1983). Size structure of phytoplankton biomass and photosynthesis in subtropical Hawaiian waters. Mar. Biol. 76: 203-211

Takahashi, M., Hori, T (1984). Abundance of picoplankton in the subsurface chlorophyll maximum layer in subtropical and tropical waters. Mar. Biol. 79: 177-186

Waterbury, J.B., Watson, S. W., Guillard, R.R., Brand, L. E. (1979). Widespread occurrence of a unicellular marine planktonic cyanobacterium. Nature, Lond. 277: 293-294

Waterbury. J. B., Watson, S. W., Valois, F.W., Franks, D. G. (1986). Biological and ecological characterization of the marine unicellular cyanobacterium Synechococcus. In: Platt, T., Li, K.W.K. (eds.) Photosynthetic picoplankton. Can. Bull. Fish. Aquat. Sci. 214: 71-120

Yentsch, C.S., Menzel, D. W. (1963). A method for the determination of chlorophyll and phaeophytin by fluorescence. Deep Sea Res. 10: 221-231

This article was submitted to the editor; it was accepted for printing on May 25, 1988 